UDC 332.13: 330.13

DOI: https://doi.org/10.37320/2415-3583/8.10

Lytvynenko Inna

PhD student, Department of Management and Innovation, International University of Finance

Ermias Russom Abrahm

Student, Department of Management and Innovation, International University of Finance

\title{
DIGITAL TRANSFORMATION OF CONSUMERS: STUDY ON THE BASE OF DHL EXPRESS IN ERITREA
}

\begin{abstract}
Digital innovation starts with a problem worth solving. We've found it's amazingly helpful to have a single statement that represents the nature of the problem, which's experiencing it, and why it's so important to solve. There for the main problem is "To what extent consumers are fitted and accepted Digital transformation attributes". This research could serve as a base for further investigation and improvement on the DHL express in Eritrea. Enhance our understanding of digital system and consumers driving. Moreover, it will contribute to the understanding of whether consumer are accepted and satisfied the digital transformation system in a developing country context. This research could also serve as a base for anyone who wants to study about how much consumers are accepted the digital transformation driving on them without any compliment on Postal Express service delivered in Eritrea. In addition, it will create a sense of awareness to the people who are engaged in offering digital system services on DHL. To undertake this research paper, primary and secondary data used. Primary data gathered by distributing online questionnaire to a sample of consumers. Secondary data extracted from several sources such as internet, magazine, books, periodicals, journals, company documents, etc. This research focuses on the digital transformation of consumers on DHL express despite the fact that consumer driving in digital transformation system is critical issue in any type of business. It focuses only on transformation from analog to digital system on consumers in experience on DHL express. It doesn't concern about the technical issues of the DHL express over the entire world.
\end{abstract}

Key words: digital transformation, digital experience, digital customer experience, digitalization.

JEL classification: C1, C13, C19, C38, D11, D12.

Formulation of the problem. Nowadays Digital transformation forcing companies to change their business models and adapt to the new market reality. What's interesting about this is that it's not the companies that are driving this change. Instead, this change is being driven by the customer. Today, customers expect relevant content in relation to what they're doing anytime, anywhere and in the format and on the device of their choosing. It's their journey that dictates your strategy.

Digital transformation is the integration of digital technology into all areas of a business, fundamentally changing how you operate and deliver value to customers. It's also a cultural change that requires organizations to continually challenge the status quo, experiment, and get comfortable with failure. It is an imperative for all businesses, from the small to the enterprise. That message comes through loud and clear from seemingly every keynote, panel discussion, article, or study related to how businesses can remain competitive and relevant as the world becomes increasingly digital. What's not clear to many business leaders is what digital transformation means. Some leaders feel the very term "digital transformation" has become so widely used, so broad, that it has become unhelpful. You may not love the term. But love it or not, the business mandates behind the term - to rethink old operating models, to experiment more, to become more agile in your ability to respond to customers and rivals aren't going anywhere. This definition answers some of the common questions around digital transformation and provides clarity, specifically to CIOs and IT leaders, including lessons learned from your peers and digital transformation experts. Because technology plays a critical role in an organization's' ability to evolve with the market and continually increase value to customers, CIOs play a key role in digital transformation. Because digital transformation will look different for every company, it can be hard to pinpoint a definition that applies to all. However, in general terms, we define digital transformation as the integration of digital technology into all areas of a business resulting in fundamental changes to how businesses operate and how they deliver value to customers. Beyond that, it's a cultural change that requires organizations to continually challenge the status quo, experiment often, and get comfortable with failure. This sometimes means walking away from long-standing business processes that companies were built upon in favor of relatively new practices that are still being defined.

If you're unfamiliar with the term, "digital transformation" refers to the ways in which businesses change to adapt to new technology and consumer preferences. It's essentially an umbrella term for the many 
changes that companies have had to make (and will continue making) to keep up-to-date with advances in tech. And at this point, it's somewhat inevitable. To say that technology has advanced over the past few years would be a massive understatement. The ways in which most businesses now operate and interact with customers are drastically different from what they were a decade ago. And though this has meant a lot of change and adjustment, many of those changes have been for the better. For example, it's now more convenient than ever for consumers to research their options, learn about different brands, and makes purchases all from the comfort of their own homes.

Analysis of recent researches and publications. This chapter assesses digital transformation of consumers, case study on DHL express. Thus, it will provide us with some basic concepts of digital transformation of consumers and some related issues like; digital transformation drives consumer experience, difference between digital experience and digital customer experience, how digital transformation can improve customer experience, etc. This literature review will refer to different scholars' concepts and studies mainly about digital transformation of consumers.

To begin with if we refer to some scholastic treatises, they infer that, With the rise of new digital technologies, e.g., social networks, mobile, big data, etc., firms in virtually all industries domains are conducting multiple initiatives to explore and exploit their benefits $[7 ; 11]$. This frequently involves transformations of key business operations and affects products and processes, as well as organizational structures, as companies need to establish management practices to govern these complex transformations [10]. Thus, the society as a whole is facing a fast and radical change due to the maturation of digital technologies and their ubiquitous penetration of all markets [4]. To add to the increased demand from customers, companies are facing ever tougher competition due to globalization [16] and putting pressure to go digital before others do, seeking to survive and attain competitive advantages [1]. Hence, in recent years "born digital" pioneers (e.g., Amazon, Facebook and Google) have grown into powerful behemoths, while companies that long dominated their industries found their traditional value proposition under threat [13]. However, despite the multiplicity of technological novelties and recipes for their implementation, whether in business, public governance and private life, real Digital Transformation is taking much longer and facing more difficulties than it has been expected [19]. Unfortunately, there are many recent examples of organizations that have been unable to keep pace with the new digital reality: examples include the bankruptcy of movie-rental Company Blockbuster, largely resulting from those firms' inabilities to rapidly develop and implement new digitally-based business models [9]. Successful
Digital Transformation requires an organization to develop a wide-range of capabilities, which will vary in importance depending on the business context and the specific organization's needs. Digital technology needs to become central to how the business operates, and organizations effectively need to re-think and possibly re-invent their business models in order to remain competitive [2]. This article differs from previous literature reviews as it strictly focuses on the concept of Digital Transformation. Several concepts have been advanced to label Digital Transformation (e.g. digitalization, digitation) and whereas they are often used indistinctively in the literature, researchers continuously try to determine their boundaries to avoid overlaps. We felt that it would be not prudent to define several terms in such a short paper; while, at the same time, there was a need to draw attention to Digital Transformation, as few literature reviews were conducted when compared, for instance, with the Digitalization term. Henriette et al [8], conducted a similar systematic literature review, but used a different database (Scopus). Their work also focuses on the vulnerabilities and opportunities of digital transformation, but different contributions arise by emphasizing the impact of digital capabilities on the digital transformation and the explanation on how digitalization transforms business models, operations processes and user experience.

In recent years, firms in almost all industries have conducted a number of initiatives to explore new digital technologies and to exploit their benefits. This frequently involves transformations of key business operations and affects products and processes, as well as organizational structures and management concepts. Companies need to establish management practices to govern these complex transformations. An important approach is to formulate a digital transformation strategy that serves as a central concept to integrate the entire coordination, prioritization, and implementation of digital transformations within a firm. The exploitation and integration of digital technologies often affect large parts of companies and even go beyond their borders, by impacting products, business processes, sales channels, and supply chains. Potential benefits of digitization are manifold and include increases in sales or productivity, innovations in value creation [10].

Digital experience should not be confused with digital customer experience. There is a difference between these two terms, but despite this, these terms are often used interchangeably. We're going to take a look at what the difference is and why it's important to understand the distinction between the two.

The term "digital experience" refers to the vast number of digital channels that organizations operate on and use. The key here is that digital experience refers to a single interaction. In contrast, digital customer experience refers to all the digital interactions 
that a customer - or potential customer - has with a business, across multiple digital channels. Digital experience can be applied to any person who interacts with an organization, whether they're an employee, business partner or a customer. Digital customer experience is therefore a sub-category of digital experience and applies to the people who might buy your products or services.

When organizations take steps to improve digital customer experience, it involves looking into anything that can lead to great customer satisfaction through digital channels. This could be improving user experience, communicating better with customers, speeding up website pages load times, improving personalization and more, across all digital interactions rather than just a singular touchpoint.

Consumer expectations are higher than they've ever been before. It's becoming increasingly important for companies to improve interaction with their employees, business partners and ultimately their customers, and digital technology is one of the best ways to do this. The time to invest in improving digital customer experience is now and this requires investment in the right technology to do this effectively [14].

Research from IDC shows that two-thirds of CEOs from Global 2,000 companies are planning on moving away from traditional strategies to modern digital ones by the end of 2019. What is the reason? The improving the customer experience. In fact, more than a third of organizations have already started integrating and executing a digital-first approach this fast-paced race towards digitally transforming even the most traditional businesses is forcing companies to change the way they operate. But this isn't being driven by the companies themselves or even the market in general, it's being driven by customers. Consumers of today want interactions that tie into what they're doing at all times and are compatible with the device they're using.

In other words, they are always connected and, in order to keep up with them, businesses need to embrace technology to provide customers with the experience they crave. With so many options available today, consumers want a unique experience that's tailored specifically to them and their needs. This means they want recommendations based on their personal preferences and their previous purchasing history - much like when e-commerce sites like Amazon recommend other "products you might like". According to a study by Accenture, $75 \%$ of consumers claim they are more likely to buy from a brand that addresses them by their name, is aware of their purchase history, and recommends products based on what they've bought in the past, and surprisingly, they are happy for companies to tap into their personal data to make those recommendations, including things like their location data, their age, and their interests [7].
Customers are not only more connected through new devices and apps they are also more social and have more nuanced needs. To connect with today's customers and endear loyalty, businesses should be at the right place (virtually or physical), with the right message or offer, at the right time every time. In order for this to happen, brands must digitally transform to meet the evolving needs and expectations of their customers by aligning the types of experiences it is delivering and tuning its internal organization, processes and technologies to enable them (fig. 1).

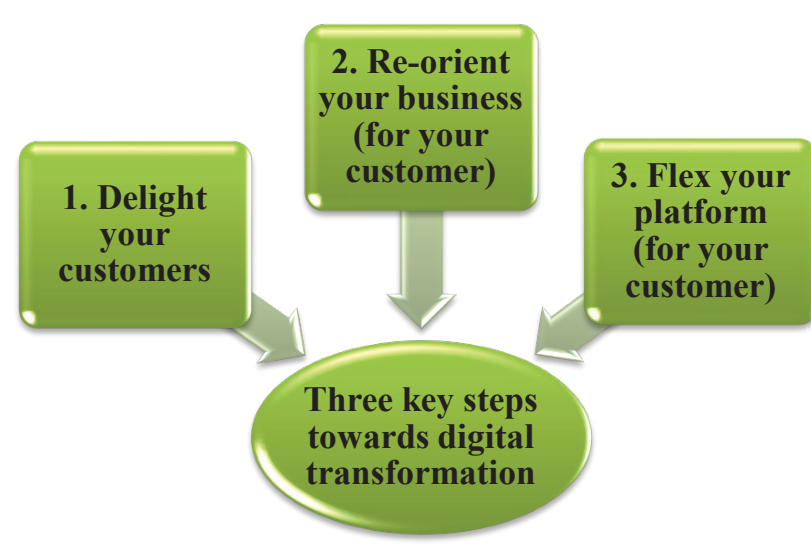

\section{Figure 1 - Three key steps towards a customer-focused digital transformation}

Source: compiled by the authors on the basis of source [5]

The purpose of the article are summarized as follow:

- to investigate whether consumers are accepted the digital transformation system changing from analog;

- to find the attributes which make consumers expect the digital transformation system delivered services.

Presentation of the main research material. The objective of this chapter is to develop conceptual framework and data collection methodology related to digital transformation of consumers in DHL express. The conceptual framework will give us a pictorial description of the major variables which are involved in digital transformation of consumers. And the data collection methodology will contain about sampling, data collection instrument, unit of analysis, and data analysis.

A conceptual framework is a short description of the major variables operating within the area of the problem to be pursued. Conceptual framework is just like a map with conceptual directions. The framework either anticipates or directly presents the basic design of the study after the literature is completed. Here is the conceptual framework of digital transformation of consumers (fig. 2). 


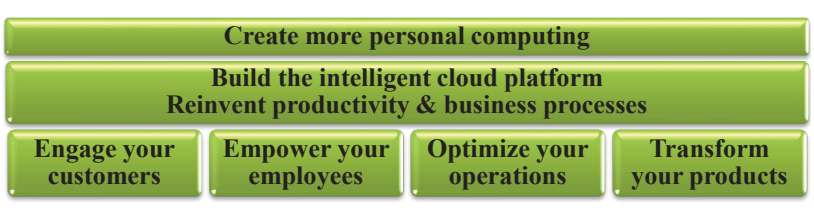

Figure 2 - Digital Transformation and consumer's experience

Source: compiled by the authors on the basis of source [12]

DHL Worldwide Express, a privately held worldwide delivery service comprised of DHL Airways and DHL International, is the world's oldest and largest international air-express company. Since 1969 when it began as an air-courier service from California to Hawaii, the firm has grown phenomenally and dominates the global express marketplace, delivering to over 70,000 destinations in 227 countries. DHL delivers both small and heavyweight parcels to destinations from the Middle East and Pacific Rim countries to throughout Europe and the United States. DHL's ever-expanding international presence prompted such stateside competitors as Federal Express and United Parcel Service, as well as the United States Postal Service, to join the fray of global express delivery.

For this research, data will be collected from consumers through questionnaire. The questionnaire is framed with three parts. The first part includes two questions. The second part includes seven questions which are related to consumers are fitted and accepted about changing of digital transformation from analog. The third part also includes five questions which are related to Consumers expect about the digital transformation system delivered services. All the questions are close end.

To conduct this research, random sampling technique will be applied. Consumers that are going to be included in that study will be chosen at random from the population. For our study, population is all the consumers that use DHL express postal service for their personal use and companywide. So, from that we are going to take a sample of 14 . Also all consumers will have equal probability to be taken as sample. The sample will be conducting through online system (E-Questioning).

This research paper, will take individual consumers of DHL express.

Data will be analyzed qualitatively and quantitatively. In quantitative analyses data will be analyzed numerically, it will include frequency and percentage table. In qualitative analyses non numerical data interpretation will be applied. Therefore, the gathered data will be entered it to Excel then it will be analyzed with help of the SPSS software (version 20).

This chapter provides us the data analysis part which is integrated with the theoretical framework regarding the Digital transformation of consumers on DHL express. The data analysis is applied in a literature review base, in order to show and compare the theory with reality. The study was conducted by gathering information from the key customers of DHL express. The 14 customers were selected randomly up on which 8 males and 6 females and their average age are 44 . The 46.7 percent of the respondents were governmental offices and from the remaining 33.3 percent were private institutions and 20 ordinary (43 percent female) and regular customers (57 percent male). The respondent's gender with respect to their educational level is represented in graph below (fig. 3).

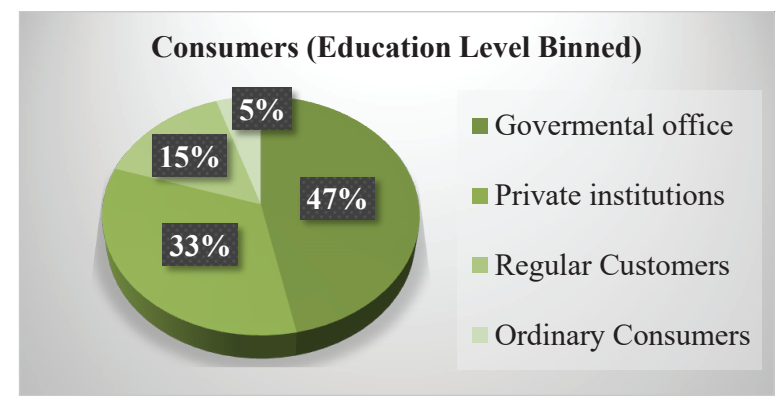

Figure 3 - Demographic respondents

Digital transformation is really countable when the customer experience is enhanced. Can you say that, with the help of smart devices, high connectivity and smart application, customer experience and satisfaction are improving? Yes, digital transformation is developing and things are surely changing around it. The world is evolving so faster towards digital that now digital transformation is predictable and trending. Every company in the market is trying to focus on moving their business online and provide better customer experience. With continued development in the technology sector, many of the companies are trying to focus on developing a smarter application than the competition. Here, we understand that digital transformation is not only about choosing smarter solutions for business, but it is about providing better services. Here, companies have realized that without digital transformation even a well-established company may vanish. The question you should be asking is, are you providing better customer experience? In this research, we tried to analyze the gathered data by taking a sample of three questions, which are directly related to the transformation and enhanced of consumer service quality (table 1).

Then we categorized according the score, which is those who scored $0-18$ as having low quality, 19-27 as having moderate quality, $28-36$ as having high quality, and $37-45$ as having very high quality on DHL express. The finding shows that 50.0 percent of the customers have very high quality on the DHL express service from digital transformation change. It also shows that $28.57 \%$ percent of the feedback they hold on their minds are created from advertisement 
Table 1 - Transformation service quality

\begin{tabular}{|c|c|c|}
\hline $\begin{array}{c}\text { Transformation } \\
\text { service quality }\end{array}$ & Frequency & Percentage \\
\hline Low & 0 & $0 \%$ \\
\hline Moderate & 3 & $21.43 \%$ \\
\hline High & 4 & $28.57 \%$ \\
\hline Very High & 7 & $50 \%$ \\
\hline
\end{tabular}

and another $28.57 \%$ percent from word of mouth and the remaining percentage is from family and friends as well as other sources (table 2).

Table 2 - Source of feedback

\begin{tabular}{|l|c|c|}
\hline Source of feedback & Frequency & Percentage \\
\hline Advertisement & 4 & $28.57 \%$ \\
\hline Family and & 2 & $14.29 \%$ \\
\hline friends & 3 & $21.43 \%$ \\
\hline word of mouth & 4 & $28.57 \%$ \\
\hline Others & 1 & $7.14 \%$ \\
\hline
\end{tabular}

Consumer expectations are higher than they've ever been before. It's becoming increasingly important for companies to improve interaction with their employees, business partners and ultimately their customers, and digital technology is one of the best ways to do this. In our case of DHL express, 50 percent of the consumers are too influenced and 42.86 percent are influenced, it also shows that only 7.14 percent are somewhat influenced by the digital transformation of DHL express, $0.0 \%$ percent are un influenced (table 3 ).

Table 3 - Digital Transformation on consumers experience and Influential effects

\begin{tabular}{|l|c|c|}
\hline $\begin{array}{c}\text { Transformation } \\
\text { on Consumers Experience }\end{array}$ & Frequency & Percentage \\
\hline Un Influenced & 0 & $0 \%$ \\
\hline Too un Influenced & 0 & $0 \%$ \\
\hline Influenced & 6 & $42.86 \%$ \\
\hline Too Influenced & 7 & $50 \%$ \\
\hline Somewhat Influence & 1 & $7.14 \%$ \\
\hline
\end{tabular}

Though the percentage of the influenced consumers by the digital transformation of DHL express is effective. The main reasons of using DHL express are that user friendly in technology and because there is no need any steps, simply using google or mobile applications (table 4).
Table 4 - Digital transformation Influential reasons

\begin{tabular}{|l|c|c|}
\hline \multicolumn{1}{|c|}{ Influential reasons } & Frequency & Percentage \\
\hline User friendly in Technology & 6 & $42.85 \%$ \\
\hline Accessibility & 3 & $21.43 \%$ \\
\hline Customer services & 3 & $21.43 \%$ \\
\hline Brand of the company & 1 & $7.14 \%$ \\
\hline Price & 1 & $7.14 \%$ \\
\hline
\end{tabular}

If we see it in figures, $21.43 \%$ percent of the consumers choose DHL express because of Accessibility and Customer services. Among the many importance of consumers influence is, when customers get satisfied they repeat services update with current technology. From the respondents 64.29 percent will definitely using DHL express again and the majority, which is 35.71 percent, will probably use DHL express in the future, if they are updated with technological services (table 5).

Table 5 - Repeat Service in future

\begin{tabular}{|l|c|c|}
\hline \multicolumn{1}{|c|}{ Repeat Services } & Frequency & Percentage \\
\hline Definitely & 9 & $64.29 \%$ \\
\hline Possible & 5 & $35.71 \%$ \\
\hline Unlikely & 0 & $0 \%$ \\
\hline No & 0 & $0 \%$ \\
\hline
\end{tabular}

There are many different factors which are helpful towards consumers repeat using future services. As we people are different from one another in our look, color, behavior the factors that satisfy us also differ. But generally people agree on the performance of some factors which really help in using express services. In this research, 71 percent of the consumers agree on user friendly technology as very important factor for their service express experience.

Next comes accessibility, which is 64 percent agreed as very important factor. Then comes customer services which are 57 percent. So performance on these attributes is very important for consumers. Also there are other factors which consumers really need them for their service performance like brand and price, 50 and 42 percent respectively (table 6). But the top three factors for high performing digital transformation attributes on consumers experience on DHL express as per this study are user friendly in Technology, Accessibility, and Customer services. Despite the fact that price is an important factor for consumers service on DHL express prefer Technology more than anything else.

Table 6 - Importance of high-performing digital transformation attributes

\begin{tabular}{|c|c|c|c|c|}
\hline & Very important & Important & Somehow important & Not important \\
\hline Technology & $71.4 \%$ & $14.3 \%$ & $14.3 \%$ & $0 \%$ \\
\hline Accessibility & $64 \%$ & $21.43 \%$ & $14.23 \%$ & $0 \%$ \\
\hline Customer services & $57 \%$ & $28.57 \%$ & $14.3 \%$ & $0 \%$ \\
\hline Brand & $50 \%$ & $35.7 \%$ & $14.3 \%$ & $0 \%$ \\
\hline Price & $42.86 \%$ & $42.86 \%$ & $14.28 \%$ & $0 \%$ \\
\hline
\end{tabular}


This study signifies that the consumers of DHL express have high experience in all the variables which is mentioned on this study. Even, they got on the ground is high experience in user friendly in technology, because of digital transformation system. Let's see the comparison of consumers ${ }^{\text {ee }}$ experiences with the actual perceived service. If we try to see the finding according the score which is provided in the study. Among the respondents, 8 were with very high experience in technological transformation; even on the ground perceive high performance in digital transformation. This signifies that there is no gap between consumers experience and actual service. Relatively those who have moderate experience on digital transformation system were 14 percent and the actual outcome of poor service performance was 21.43 percent. The gap is 7 percent. The graphical representation of this study is provided clearly below (table 7, fig. 4).

Table 7 - Consumer's experience

\begin{tabular}{|l|c|c|}
\hline $\begin{array}{c}\text { Consumer's } \\
\text { experience score }\end{array}$ & Frequency & Percentage \\
\hline Low experience & 0 & $0 \%$ \\
\hline Moderate & 2 & $14 \%$ \\
\hline High & 4 & $28 \%$ \\
\hline Very high & 8 & $57 \%$ \\
\hline
\end{tabular}

Conclusions. Based on the research conducted, we concluded that the consumers of DHL express fitted and accepted the digital transformation system. Majority of the consumers hold very high experience from the service. The main source of the experience feedback is from advertisement and word of mouth. Consumers compare updated technological system with the actual performance of the service; as a result they get very high experience. As it is mentioned before, one of the important factor which plays a great role towards consumers experience in digital transformation is user friendly technology. Appro-

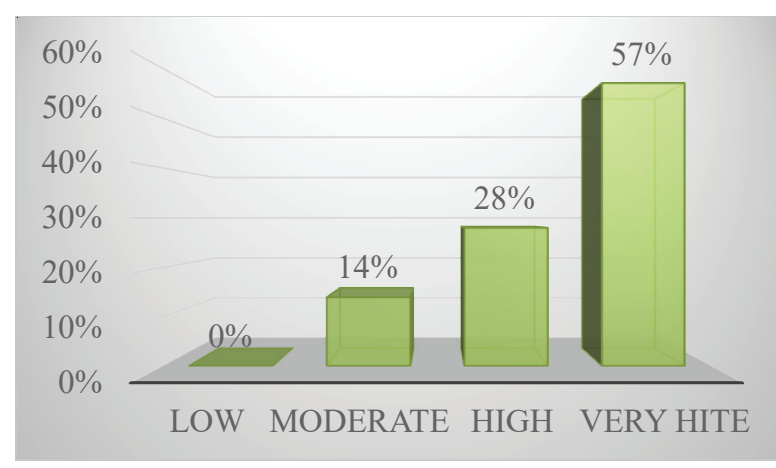

Figure 4 - Consumers experience on digital transformation

priately all type of consumers chooses DHL express from other expresses, Messt, FedEx, UPS etc. Over the Express due to accessibility. The study also high lights accessibility as the most important factor for consumers experience on DHL express than any other factors.

On general we kindly recommend the DHL to keep watching on Digital system services. Our recommendations to DHL express are as follows:

- though the overall DHL express service needs improvement on other factors, brand, price and others; digital system is very important factor for consumers service, they should give more focus to Technological system;

- significant number of consumers gets their experience from advertisement, so they must give a true picture while advertising, because consumers experience depends greatly on advertisement and using other techniques like free user manual, how to use company applications and websites and etc.;

- consumers are in need of information, so DHL express should provide proper and timely information, by updating in their mails, SMS, magazine sites and etc.

\section{References:}

1. Bharadwaj, A. (2000) "A resource-based perspective on information technology capability and firm performance: an empirical investigation", MIS Q, 24 (1), 169-196.

2. Carcary M., Doherty E. and Conway G. (2016) "A dynamic capability approach to digital transformation-a focus on key foundational themes". 10th European Conference on Information Systems Management. Academic Conferences and publishing limited, pp. 20-28.

3. Roger D.L. (2017), The Digital Transformation Playbook: Rethink Your Business for the Digital Age (Columbia Business School Publishing), published by Colombian business school.

4. Ebert C., Duarte C. (2016) "Requirements engineering for the digital transformation: industry panel". Requirements Engineering Conference IEEE 24th International, pp. 4-5.

5. Econsultancy - achieve excellence in modern marketing (2013) "Three key steps towards a customer-focused digital transformation - Econsultancy", available at: https://econsultancy.com/three-key-steps-towards-a-customer-focused-digitaltransformation (accessed: 2019).

6. Exponea Customer Data \& Experience Platform (CDXP) (2019) "How Digital Transformation is Improving Customer Experience. Exponea - Customer Data Platform", available at: https://exponea.com/blog/how-digital-transformation-is-improving-customer-experience (accessed: 2019).

7. Fitzgerald M., Kruschwitz N., Bonnet D., Welch M. (2013) "Embracing Digital Technology: A New Strategic Imperative". MIT Sloan Management Review, Research Report.

8. Henriette E., Feki M., Boughzala I. (2015) "The shape of digital transformation: a systematic literature review". Information Systems in a Changing Economy and Society, p. 431. 
9. Hess T., Matt C., Benlian A., Wiesböck F. (2016) "Options for formulating a digital transformation strategy". MIS Q, Executive, 15 (2), 123-139.

10. Matt C., Hess T., Benlian A. (2015) Digital Transformation Strategies. Business and Information Systems Engineering, vol. 57 , iss. 5 , pp. $339-343$.

11. Ross J., Sebastian I., Beath C., Scantlebury S., Mocker M., Fonstad N., Kagan M., Moloney K., Geraghty Krusel S. (2016) "Designing Digital Organizations". MIT Center for IS Research, vol. 46.

12. Sagar Nangare - Technology Blogger | Digital Strategist at Calsoft Inc. (2017) "Role of Cloud Computing in Digital Transformation - Sagar Nangare", available at: http://sagarnangare.com/role-cloud-computing-digital-transformation (accessed: 2019).

13. Sebastian I., Ross J., Beath C., Mocker M., Moloney K., Fonstad N. (2017) “How Big Old Companies Navigate Digital Transformation". MIS Quarterly Executive, pp. 197-213.

14. Unily Enterprise Intranet Solutions | Cloud Based Intranet Software (2019) "Difference between Digital Experience \& Digital Customer Experience", available at: https:/www.unily.com/digital-experience-basics/digital-experience-vs-digitalcustomer-experience (accessed: 2019).

15. Warren Keegan, Sandra Moriarity and Tom Dunkan (1995), Marketing, 1st edition, published by Prentice hall, Inc.

16. Westerman G., Calméjane C., Bonnet D., Ferraris P., McAfee A. (2011), "Digital Transformation: A Roadmap for Billion-Dollar Organizations". MIT Sloan Management, MIT Center for Digital Business and Capgemini Consulting, vol. 1, pp. 1-68.

17. William F. Schoell and Joseph P. Guiltinan (1995), Digital Marketing contemporary concepts and practices, 6th edition, published by Prentice hall, Inc.

18. William O. Bearden, Thomas N. Ingram and Raymond W. Laforge (1998), Consumers and digital transformation principles and perspectives, 2nd edition, published by Mc Graw-hill.

19. Zinder E., Yunatova I. (2016), Synergy for digital transformation: person's multiple roles and subject domains integration. Digital Transformation and Global Society, pp. 155-168.

\section{Литвиненко І., Ерімас Руссом Абрам} Міжнародний університет фінансів

\section{ЦИФРОВА ТРАНСФОРМАЦІЯ СПОЖИВАЧІВ: ДОСЛІДЖЕННЯ НА ПРИКЛАДI DНL EXPRESS В EPITPË̈}

Стаття присвячена цифрровій інновації, щзо починається з проблеми, яку варто вирішити. Ми виявили, щзо надзвичайно корисно скласти єдине твердження, яке відображає характер проблеми, хто ї̈ відчуває, чому ие так важливо вирішити. Основна мета полягає в тому, щзоби визначити те, наскільки споживачі сприймають атрибути ичифрової трансформації. Актуальність статті полягає в тому, що воно може послужити основою для подальшого дослідження та вдосконалення DHL Express в Eрітреї, а також покращує розуміння ичифрової системи та поведінки споживачів. Більше того, ие сприятиме усвідомленню того, чи сприймають споживачів та чи задовольняють вони систему цифррової трансформації в умовах краӥни, щчо розвивається. Дослідження також може послужити базою для тих, хто хоче дізнатися про те, наскільки споживачі приймають ицифрову трансформацію, використовуючи послугу Postal Express, щзо постачається в Ерітреї. Крім того, ие створить відчуття обізнаності у людей, які займаються пропонуванням изифрових системних послуг на DHL. Під час дослідження використовувалися первинні та вторинні дані. Первинні дані зібрані шляхом поширення онлайнанкети на вибірку споживачів. Вторинні дані були вилучені з кількох джерел, таких як Інтернет, журнал, книги, періодичні видання, журнали, документи компанії. Результати дослідження фокусуються на иифровій трансформації споживачів на DHL Exрress, незважаючи на те, щзо рух споживачів у системі ичифрових перетворень є критичним питанням у будь-якому бізнесі. Вона зосереджена лише на перетворенні від аналоговоі до иифрової системи на споживачах, які використовують DHL Express. Це не стосується технічних проблем DHL Express у всьому світі.

Ключові слова: ичифрова трансформація, ичифровий досвід, цүифровий досвід клієнтів, ичифровізація. 